\title{
Formativno-katehetski pristup pojmu ljepote
}

Dragomir Sando*

dragsando@yahoo.com https://doi.org/10.31192/np.17.1.8

UDK: 111.852:27-472

Pregledni članak / Review

Primljeno: 5. veljače 2019.

Prihvaćeno: 26. veljače 2019.

Značajno svojstvo pedagogije jest ljepota. Ona u širem smislu označava sve ono što potječe od estetskoga, ali i egzistencijalnoga. Njezini korijeni su još od vremena $i$ načina stvaranja $i$ poretka postojanja svijeta, ali i njegova krajnjeg smisla, a samim tim i odgojno-obrazovnog ustrojstva u svijetu. Ljepota tako postaje svojstvo kozmoloških, antropoloških, teoloških, eklezioloških, socioloških $i$ drugih odlika svijeta. Čovjek je stvoren kao lijepo biće, kao savršeno lijepo, ali nedovršeno biće, $i$ kao takav je nositelj mogućnosti vječnog života, stvaran $z a$ lučonošu primatelja božanske svjetlosti i ljepote. Čovjek kao slika Božja $i$ jest stvoren s namjerom da bude savršeno lijep i prosvijetljen jer je »slovjesan«, suobličen Bogu, jer je bogolik i stvoren za nešto mnogo uzvišenije i neusporedivo vrjednije od svega što postoji.

Ključne riječi: ljepota, Crkva, stvaranje, estetika, umjetnost, obrazovanje, odgoj.

\footnotetext{
* Dr. sc. Dragomir Sando, Pravoslavni bogoslovski fakultet, Univerzitet u Beogradu, Mije Kovačevića, 11b, SRB-11060 Beograd.
} 


\section{Uvod}

Jedno od osnovnih svojstava, uopće, kršćanstva i Crkve jest estetika ili pojam ljepote. Nekadašnji pedagog i profesor Pravoslavnoga bogoslovskog fakulteta u Beogradu Radmilo Vučić (1957-1976) crkvenu je pedagogiju utemeljio na četiri osnove: znanost (kao istinu), moralnost (kao dobrotu), religioznost (kao svetost) i estetiku koja poprima izraze lijepoga i umjetničkog.

»Čovek u svom iskustvenom svetu sreće se, manje više, sa iskustvom lepog, ljupkog, tragičnog, veličanstvenog. (...) Opisujući to na razne načine: rečima, slikom, rezbarenjem, pokretima (...) on stvara umetnost..« ${ }^{1}$

On svakako doživljava da i Stvoritelj iskustvenog svijeta nesumnjivo ima osobine estetskoga. Apsolutna ljepota je njegova osobina. Zato svako njegovo djelo ima iste odlike. U umjetnosti se čovjek približava Bogu izražavajući osobine njegova djela. Ljepota i harmonija, tragično i ljupko nisu odlike samo iskustvenog svijeta nego i apsolutne stvarnosti; one čine njezinu bit, njezinu srž. Zato umjetnost duhovno uzdiže i oplemenjuje čovjeka jer umjetnička djela imaju nadvremensku vrijednost. Stvarajući ih, čovjek se oslobađa prolaznosti i ostvaruje neki svijet koji je viši od prirodnoga i koji ne propada. Kad god stvara, čovjek se trsi iznjedriti nešto lijepo, nešto estetsko, nastoji mu na taj način pružiti trajnu vrijednost. Isto je tako i u pogledu ponašanja, govora i pisanja i svake čovjekove aktivnosti. Kršćanska umjetnost nalazi poticaj i gradivo za nešto dublje, a to su stvaralačke težnje za misaonim poletom i težnja za tumačenjem apsolutnog svijeta. ${ }^{2}$ Umjetnik traži trajno, vječno, božansko u čovjeku i ono što u svijetu ukazuje na sveprisutnost Božju; on se ne zadržava na površini pojava, ne slika samo tijelo, nego duh, najdublje spoznaje i zanose, raspoloženja i težnje. Zato umjetnost bez religioznog temelja postaje površna i bezidejna. ${ }^{3}$

Cilj Božje pedagogije jest čovjekovo spasenje od grijeha i njegovih posljedica. Spasenje je vraćanje čovjeka njegovu prvobitnom zdravlju. To se postiže Božjom milošću i čovjekovim asketskim prihvaćanjem Božje milosne snage, prihvaćanjem da je vrlina, tj. život po Bogu i u Bogu, jedini prirodan i normalan način ljudskog postojanja. ${ }^{4}$ Vrlina je, kao plod usklađivanja s Bogom, unutarnji ritam čovjekova življenja i rasta u najtješnjem odnosu s ljepotom, estetikom, tj. dubljim načinom života.

Kada se spomene lijepo i ljepota, prva asocijacija su ljudska osjetila i osjećaji. Čovjek je biće koje, između ostaloga, osobito egzistira s pomoću osjetila. I sva osjetila su usklađena radi »viših« potreba čovjekova življenja. Osjećaj ljepote za osjetilo vida značiti će shvaćanje »ikoničnosti«. Osjetila imaju svoju prijemlji-

\footnotetext{
${ }^{1}$ Radmilo VUČIĆ, Pedagogika, Beograd, 1973, 12.

2 Usp. isto, 13.

${ }^{3}$ Usp. Katekizam Katoličke Crkve, Zagreb, 1994, 528.

${ }^{4}$ Usp. Mitropolit AMFILOHIJE, Osnovi pravoslavnog obrazovanja $i$ vaspitanja, Cetinje, 2002, 51.
} 
vost za ono što ima ne samo svoj red i harmoniju, sklad i kolorit, nego i dublji smisao, posebno obrazovni, a to je da uzdiže, pokreće, motivira, preobražava cijelog čovjeka. Tako je i s osjetilom sluha, gdje se između gornjeg i donjeg praga čovjekove osjetilne moći, finom simfonijom riječi, pjesme, zvuka, tonova i komunikacije doprinosi doživljavanju vjerne ljepote. U novijim shvaćanjima ljepote kod »estetskih osjetila«, dolazi do uvjetnog odnosa lijepoga i umjetnosti, lijepoga i filozofije, lijepoga i intuicije.

\section{Pojam ljepote u antičko doba}

Osjećaj ljepote ima i svoju antičku kao i biblijsku utemeljenost. Na prvim stranica Biblije, u izvještaju o stvaranju svijeta, već deseti redak prve glave Knjige Postanka, nakon govora o stvaranju kopna i vode, dodaje: »I vidje Bog da je dobro ( $\kappa \alpha \lambda o ́ v)$ «. Iste riječi se ponavljaju i trećeg dana Božjeg stvaranja svijeta, i četvrtoga, i petoga, kao i šestoga dana: »I vidje Bog da je dobro.« A šestoga dana, kada nakon krupnijih životinja Bog stvara i čovjeka, dodaje se u tekstu Biblije još jedna riječ: »I vidje Bog sve što je učinio, i bijaše veoma dobro« (Post 1, 31a). Za sve stvoreno čovjekovim mjerilima reklo bi se: Da, sve stvoreno bijaše lijepo. Riječi dobro i lijepo ovdje imaju identičan smisao. Kod starih Grka ovaj se pojam nazivao »kalokagatija» (pripadnost dobru i lijepome). Takav primjer imamo i danas. Kada se kaže: »Vidi lijepa čovjeka«, ne misli se na njegovu tjelesnu ljepotu, nego na dobrotu. Biblijskim svjedočenjem snažno je istaknuto dobro ili lijepo koje se, ne bez razloga, više puta ponavlja u Knjizi Postanka, da je stvaranje od samog Stvoritelja istinski takvo.

Već u Septuaginti se više koristi drugi pridjev: »I vidio je Bog da je to lijepo « (Post 1, 4.10.12.18.21.25), ili: »I vidio je Bog sve što je stvorio, i gle, to je vrlo lijepo« (Post 1, 31). Ovo »lijepo« u Septuaginti ima, kako je pravilno zapazio Wladislav Tatarkiewicz, estetsku nijansu. ${ }^{5}$ Biblijsko shvaćanje stvaranja svijeta ni iz čega kao da je ponovno pred grčko-rimskom kulturom otkrilo ljepotu stvarnog svijeta i pokazalo je na nov način. Tako su osnovne biblijske ideje doprinijele razvoju estetskog shvaćanja svijeta u kršćanstvu. Ljepota i harmonija svijeta u svoj njegovoj raznovrsnosti značajni su samo kao odraz božanske mudrosti. »Sve si premudro stvorio; puna je zemlja djela tvojih« (Ps 103, 24). Lijepa podudarnost (similitude) svega postojećeg, za koju Augustin tvrdi da je »cijeli svemir od jedne do druge odgovarajuće stvari savršena ljepota koja odgovara jednoj drugoj stvorenoj ${ }^{6}{ }^{6}$

Poistovjećivanje pojmova dobro i lijepo nije jedinstvena samo u grčkim tekstovima. Kod Židova, kao i kod Grka, ljepota i dobro se sasvim malo razlikuju.

${ }^{5}$ Usp. Wladislav TATARKIEWICZ, Historia estetyki, Varšava, 1962, 101.

${ }^{6}$ Wilhelm HOFFMANN, Philosophische Interpretation der Augustinusschrift de acte musica, Merburg, 1931, 5. 
Grčki tó $\kappa \alpha \lambda$ óv u tom smislu odgovara starozavjetnom pojmu »tob«. I »tob« starožidovskog originala i »bonum« Vulgate više odgovaraju onome što je $u$ staroslavenskom prijevodu bilo preneseno kao »dobro«, to jest pozitivnu ocjenu u najširem smislu riječi. Tako su i crkveni oci prenijeli biblijsko shvaćanje ovih termina. Kod crkvenih otaca se za označavanje ljepote i lijepoga najčešće koriste tradicionalni termini to kallos, to kalon, kalon - dobar, pulchritude, pulcher, décor, nerijetko se u estetskom značenju rabe i sljedeći termini: oreos i oreoti - ugodan, ugodnost, ljubak, kozmos - ljepota, ukrašavanje. Međutim, bliskoistočni narodi su, za razliku od Grka, vidjeli lijepo u svemu što živi, što se kreće, igra, ali osobito u sili i vlasti. Osjećaj ljepote su im pružali svjetlost, cvijet, zvuk, glas, okus i slične pojave. ${ }^{8}$

Usporedba Boga kao Stvoritelja s umjetnikom, naravno, nije bila originalna u kršćana. Ona pripada cjelokupnoj duhovnoj misli kasne antike i teško je ustanoviti tko je i gdje prvi put spominje. ${ }^{9}$ Kršćani su u svjetlu kršćanske kozmologije dali nov pogled na sve i znatno su drukčije osmislili ideje svojih poganskih protivnika postavivši koncepciju Božjih stvaranja u temelj pogleda na svijet i njegov poredak. Istina je da su i ti pogledi u početku bili različiti. Justin i Atenagora su poimanje Boga kao umjetnika shvaćali približno kao i stoici: Bog uređuje i ukrašava odvijeka postojeću tvar, dok Teofil i Tacijan na Istoku, a Tertulijan na Zapadu, svjesno pokreću pitanje o posebnom božanskom stvaranju - »ni iz čega . $^{10}$ Kao što će naglasiti Aleksej Fjodorovič Losev, rana antička estetika je veliku pozornost posvećivala ljepoti dobro ustrojenog poretka. ${ }^{11} \mathrm{Za}$ Homera je najljepša napravljena stvar, dok, počevši od Platona, estetiku zanima idealna ljepota i sama »ideja« ljepote. U klasičnoj antičkoj umjetnosti glavno mjesto zauzima idealna ljepota čovječjeg stvaranja. ${ }^{12}$ Dionizije Aleksandrijski, kao tipičan predstavnik rane patristike, suprotstavlja principe novog kršćanskog estetizma antičkoj znanosti i filozofiji, antičkom shvaćanju ljepote i umjetnosti. ${ }^{13}$ Njemu ljepota prirodnog svijeta služi kao važan argument za dokazivanje postojanja božanskog Stvoritelja, dok najvišu ljepotu i istinsku nasladu nalazi u sferi budućeg preobraženog bitka i čovječanstva, kako propovijeda kršćansko učenje, odnosno u sferi idealnog bitka. ${ }^{14}$

Božanski Logos, Bogočovjek Isus Krist, postaje alfa i omega čovjekova spasenja. U njegovoj se tajni otkrivaju i ostvaruju beskrajne mogućnosti čovjekova

\footnotetext{
${ }_{7}$ Usp. Viktor BIČKOV, Estetika Otaca Crkve, Beograd, 2010, 32.

${ }^{8}$ Usp. isto.

${ }^{9}$ Usp. Aleksej FEDOROVIC (Fjodorovič) LOSEV, Eseji antičkog simbolizma $i$ mitologije, Peterburg, 1930, 84.

${ }^{10}$ Isto, 85.

${ }^{11}$ Usp. Aleksej Fedorovic LOSEV, Historija antičke estetike, Peterburg, 1978,155.

${ }^{12}$ Usp. Viktor BIČKOV, Vizantijska estetika, Beograd, 1991, 133. Platon je uspoređivao odnos ljepote između vizualnog i opažajnog.

${ }^{13}$ Usp. isto, 136.

${ }^{14}$ Usp. Thorleif BOMAN, Das Hebräische Denken im Vergleich mit dem Griechischen, Göttingen, 1959, 112.
} 
rasta, ostvarenog u njegovoj prirodi, pokazujući se kao mogućnosti sve dublje suobličenosti s Bogom i hipostatskog jedinstva (jedinstva osoba) s njime. ${ }^{15} \mathrm{U}$ Kristu se ostvaruju jedinstvene i objedinjene službe: učitelja, pedagoga i savjetnika. Kao učitelj poučava ljude najvišoj istini, kao pedagog pokazuje put pravednika i moralnog življenja i kao savjetnik poučava ljude izbjegavanju lažnoga života.

Walther Völker, jedan od zagovornika veličine i značenja estetike, konstatirat će: Pedagog je praktičar, a ne teoretičar i njegov je cilj poboljšanje duše, a ne naučavanje; njime se pokazuje život mudraca, a ne znanstvenika. ${ }^{16}$ Prije svega on dovodi u red moralno življenje; on priprema »bolesne« za potpuno ozdravljenje i za primanje najviših istina. To je moralan put pripreme znanja. Njegov temelj čine vjera, strah i ljubav. To je religiozno-etički i estetski put čovjekova usavršavanja, koji vodi k dostizanju »suobličenja s Bogom «. ${ }^{17}$ Može se dodati da je istinski pedagog i praktičar i teoretičar, onaj koji pokazuje put i mudraca i znanstvenika. Moralni kriterij je itekako važan, ali se sve ne iscrpljuje samo u njemu.

I čovjek je stvoren kao lijepo biće, kao savršeno lijepo, ali nedovršeno biće, i kao takav je nositelj mogućnosti vječnoga života, stvoren za lučonošu božanske svjetlosti i ljepote. Čovjek kao ikona Božja i jest stvoren s nakanom da bude savršeno lijep i prosvijetljen jer je »slovjesan«, jer je suobličen Bogu, jer je bogolik i stvoren za nešto mnogo uzvišenije i neusporedivo vrjednije od svega što postoji. Savršena ljepota je smisao i cilj i domet kojemu čovjek neprestano teži i u tom neprestanom nastojanju očigledno je da čovjek sam sebi ne može biti osnovni kriterij niti mjerilo krajnjih granica. Njegov istinski izraz ljepote jest Bog ili točnije Bogočovjek.

»Bogolikost, ikoničnost, ljepota čovjekova bila je i jest prvo evanđelje, praevanđelje, besmrtno evanđelje, neuništivo evanđelje. U toj bogolikosti nalazi se čovjekovo oslanjanje na Boga, i čovjekova svijest o Bogu, i čovjekova žudnja za Bogom, i čovjekova ogromna sloboda, i čovjekov vječni život, i čovjekovo otimanje od smrti i čovjekovo neumorno hrljenje ka svemu što je vječno i njegova neprestana pedagogija. $\aleph^{18}$

Po svjedočenju upućenih, antropologija zauzima najvažnije mjesto u kršćanskoj filozofiji koja nagovještava gornji, najviši prag čovjekova postojanja. Razumije se, valja imati u vidu da bez proučavanja problema čovjeka ne može biti dokraja shvaćen gotovo nijedan ključni element kršćanske kulture, uključujući i estetiku i umjetničku kulturu. Za apologete se sav kozmos kreće između dva pola - Boga i čovjeka. Čovjek je glavno i ljubljeno stvorenje Božje. Briga

\footnotetext{
${ }^{15}$ Usp. Mitropolit Amfilohije, nav. dj., 38.

${ }^{16}$ Usp. Walther VÖLKER, Das Vollkommenheitsideal des Origenes. Eine Untersuchung zur Geschichte der Frömmigkeit und zu den Anfängen christlicher Mystik, Tübingen, 1931, 84.

${ }^{17}$ Walther VÖLKER, Der wahre Gnostiker nach Clemens Alexandrinus, Berlin - Leipzig, 1952, 251.

${ }^{18}$ KIRIL JERUZALEMSKI, Kateheze, Cetinje, 2002, 11.
} 
o njemu je osnovna zadaća Božjih djelovanja i promisli. Radi spasenja i vječnoga blaženstva čovjek i teži k Bogu. Posvećujući, u izgradnji svoje osobnosti, pažnju božanskom autoritetu, čovjek pažljivije zagleda u sebe i lakše nalazi ne samo Boga nego i sebe. U povijesti kulture nastupio je trenutak kada je čovjek počeo razumijevati da mora biti čovječan, da je čovječnost njegova osnovna vrijednost, što dotad nije bio kadar shvatiti velik dio čovječanstva. Tek je kršćanstvo, nacrtavši na svojim znamenjima lik Bogočovjeka koji trpi za druge, prvi put u povijesti kulture svjesno diglo glas u zaštitu slabog, unesrećenog i trpećeg čovjeka, pokušavajući i teoretski obrazložiti i dokazati (oslanjajući se na božanski autoritet) da čovjek mora biti prije svega čovječan. Upravo od kasne antike, a osobito od apologeta, dovodi se u kontekst podrijetlo pojma čovječnost. ${ }^{19}$

Po Klementovu nauku, istinska ljepota je skrivena u čovjeku: ona je sadržana i u čovjekovoj duši i u njegovu tijelu. Naravno, Gospodin prirodnu ljepotu tijela, u nekom smislu, cijeni manje od ljepote duše. Posljednja se pojavljuje u vrlini i neraskidivo je povezana s dobrom. Samo je čovjek onaj kojeg odlikuju vrline, istinski к $\alpha \lambda$ ó $\kappa^{\prime} \alpha \gamma \alpha \theta$ óc. Prema vrlini pak vodi razum, pa stoga, ako čovjek želi biti lijep, on mora u sebi razvijati tu najljepšu sposobnost - razum. Takav čovjek mora težiti k spoznaji istine, mora živjeti s Logosom i u sebi imati »obličje Logosa « te na kraju "postati sličan Bogu« jer tek tada će postati »istinski lijep«. Njegova vrlina, to jest ljepota duše, može se očitovati i u ljepoti tijela. $^{20}$

\section{Ljepota u Bibliji}

Da se ljepota kao pojam mnogo šire shvaćala, a samim time imala i odgojnoobrazovni karakter, znalo se još u drevnim vremenima. Hedonističko je shvaćanje ljepote u uživanju gledanja i slušanja, tj. u takozvanim »višim osjetilima«. Estetski izričaj ne ovisi o prirodi dojmova, nego dojmovi svih naših osjetila mogu biti uzdignuti do izraza. ${ }^{21}$ Pedagoški vid ljepote sagledavali su u utilitarističko-moralističkom viđenju da ljepota po umjetnosti doprinosi moralnoj svrsi života. Da sve ne bi ostalo odveć površno, valja se iznova vratiti drevnim sofistima. Kod Grka, a i Rimljana, tvrdi se da čista i naivna radost pomaže djelo onoga koji radi za istinu i za dobro. To shvaćanje ljepote nije nikako u fizičkom

\footnotetext{
${ }^{19}$ Poznata sentenca sofista i retora klasičnog vremena Protagore: »Čovjek je mjera svih stvari« - onih koje jesu da jesu i onih koje nisu da nisu - nema nikakve veze s tom čovječnošću. Ona u kontekstu Protagorine subjektivističke i relativističke gnoseologije znači da objektivna istina ne postoji uopće, da samo različita mišljenja ljudi prihvaća kao istinita (vidjeti: Johannes IRMSCHER (ur.), Lexikon der Antike, Leipzig, 1979, 454).

${ }^{20}$ Usp. Bičkov, nav. dj., 344.

${ }^{21}$ Usp. Vjačeslav PAVLOVIĆ ŠESTAKOV, Doktrina harmonije u historiji estetske misli, b.m., 1973, 54.
} 
izgledu već u čovjekovoj aktivnosti, u njegovoj duhovnoj snazi. Fizičke stvari su samo pomagači u reprodukciji lijepog, ili u eliptički lijepim stvarima, u odnosu na fizičku ljepotu. Sadržaj riječi »lijep« privukao je pažnju oštroumnih mislilaca i profinjenih ukusa, osobito kritičara stare Helade. Kod Sokrata tim pitanjem, sačuvanim u jednom razgovoru kod Ksenofonta, vidimo da se za tren zaustavio pri zaključku da je lijepo ono što pristaje i odgovara svrsi ili, prema drugom zaključku, da je lijepo ono što volimo. ${ }^{22}$ Kod Platona ponuđena su razna rješenja ili pak samo njihove konture. On govori o lijepome koje nije samo u tijelima već i u zakonima, u zanimanjima, u znanostima; čini se da lijepo donekle povezuje i poistovjećuje s istinom, s dobrim i božanskim; nekad se opet vraća Sokratovoj koncepciji i zamjenjuje ga s korisnim; zatim razlikuje lijepo samo u sebi i po sebi (kala kat avta) i dijeli ga od relativno lijepog (pros ti kala); malo vidi pravu ljepotu u čistom uživanju, slobodnom od svake sjene boli; ili je unosi u mjeru proporcije ili smatra boje i tonove za lijepe same po sebi. Kad je isključio mimetički smisao, nemoguće je bilo da se lijepome nađe odgovarajuće područje.

U filozofskoj misli teško je pobrojiti sve koji su se krucijalno bavili pitanjem ljepote jer je, po uzoru na Platona i njegova djela Gorgiju, Fileba, Fedru, to bila omiljena tema mnogih nasljedovatelja i mislilaca na raznim poljima. ${ }^{23}$ Platon je htio osuditi samo umjetnost svoga vremena, naturalističku i realističku, antičku umjetnost uopće, koja nosi u sebi značajku nečega što je konačno. ${ }^{24}$ Ali on ne bi nikada ponovio svoju osudu da je kojim mogućnostima upoznao kršćansku umjetnost čiji je karakter beskonačnost. Nedovoljna je čista apstraktna ljepota »a la Winckelmann«, pogrešan je i negativan pojam karakterističnog, kome je svrha od umjetnosti napraviti mrtvu, oštru i nedopadljivu stvar time što je uokviruje uskim okvirom individualnog. ${ }^{25}$ Umjetnost je $\mathrm{u}$ isti mah i ljepota $\mathrm{i}$ »karakterna ljepota«, karakter iz kojega se razvija ljepota i, prema tome, ona nije jedinka već živi pojam jedinke. ${ }^{26}$ Kad umjetnikov pogled spozna u jedinki stvaralačku ideju, i iz nje je izvede, on preobražava tu jedinku u svijet za sebe, u posebnost (Gattung), u vječitu ideju (Urbild) i ne plaši se više ograničenosti i teškoće, koja je uvjet našega života. Karakterna ljepota je punoća forme koja uništava tu formu, čime se ne umanjuje strast, već samo obuzdava, kao korito rijeke što ga valovi ispune, ali ga ne preplavljuju. ${ }^{27}$

\footnotetext{
${ }^{22}$ Usp. Benedetto CROCE, Estetika, Beograd, Kosmos, 1934, 380.

${ }^{23}$ Usp. Bickov, nav.dj., 32.

${ }^{24}$ Usp. isto, 105.

${ }^{25}$ Usp. August Dethard KALKMANN, Tatians Nachrichten über Kunstwerke, Rheinisches Museum für Philologie, 42 (1887) 489-524.

${ }^{26}$ Usp. Croce, nav. dj., 380.

${ }^{27}$ Usp. isto.
} 


\section{Pojam ljepote u kršćanstvu}

Pojam ljepote, na temelju osvjedočenoga, provjerenoga, inspirativnoga, dobiva svoju punoću upravo u kršćanstvu. »Sofija Božja«, koja je otkrivena u Kristovoj Crkvi i kršćanstvu, čini Crkvu trajnom školom. U njoj, kao takvoj, učenje je nepestano. Crkva, kako u svojoj prirodi tako i u svom djelovanju, daruje ne samo znanje već i puteve za njegovo stjecanje, i u tom smislu najznačajnije su vrline. Sve što ona jest i što joj je svrha, prema riječima apostola Pavla, jest to da vjernici »mognu shvatiti sa svima svetima što je Dužina i Širina i Visina i Dubina« $(E f 3,18)$ Crkve nazidane »na temelju apostolâ i prorokâ, a zaglavni je kamen sam Krist Isus« (Ef 2, 20), te »spoznati nadspoznatljivu ljubav Kristovu da se ispunite do sve punine Božje« (Ef 3, 19). Svjetlost kršćanske antropologije putem obrazovanja ne znači samo nagomilavanje znanja, već i biti hranjen gojen Kruhom Života. ${ }^{28}$ Ili, koristeći riječi svetog Serafima Sarovskog, »stjecati Duha Svetog«. To otajstvo kršćanstva i Crkve, u kojem svijet i čovjek dostižu svoju puninu, prepoznajemo i prigrljujemo u komuniciranju (općenju), u obrazovanju i odgoju. Cjelokupna Božja objava Staroga i Novog zavjeta živi kao pedagoško sjećanje (anamneza), ali i kao stvarnost, kroz djelovanje Duha Svetoga. To je jedinstvena stvarnost i jedinstven, ali općenit primjer prosvjećivanja.

Kao način i mjesto gdje kršćanin prepoznaje Krista kao svoga Učitelja, ili, bolje rečeno, gdje on kršćane prepoznaje i grli kao svoje (usp. Gal 4, 9) jest prostor Crkve. Prema tome, Crkva kao savršena škola pokazuje se ne samo kao teorija ili kao ona koja odgaja um, nego kao ona koja kršćansko biće prožima ljepotom u svim vremenima. Kršćanin je uvijek od svoga početka u školskim klupama Božje nastave gdje sudjeluje u njoj i u bogoslužju i u življenju vrlina. Ako vjernik svoje krštenje naziva prosvjetljenjem, ono se nastavlja u sakramentu svete potvrde (miropomazanju), svete pričesti (euharistije) i svim ostalim sakramentima kao svetim otajstvima ili svetim tajnama. U liturgijskoj katehezi (pouci) otkriva se etos Crkve. Štoviše, etos Crkve je stjecanje istinskoga znanja, moralnoga života, pa i općeg znanja, te slavljenja Boga kao savršene pouke. Biblijske istine su kao stijenj i ogledalo svakoj nadahnutosti. Jer »naš je nauk sukladan životu Crkve, a naš praktičan bogoslužni život potvrđuje naš nauk«, reći će sv. Irenej Lionski. ${ }^{29} \mathrm{U}$ Crkvi stječemo znanje i odnos prema nebeskim anđeoskim silama, u njoj učimo živjeti i misliti s onima koji su sveti. ${ }^{30}$ To praktično znači da se to vrijeme i način može smatrati početkom starokršćanske umjetnosti. $^{31}$

\footnotetext{
${ }^{28}$ Usp. Dragomir SANDO, Bogosluženje kao osnova obrazovanja i vaspitanja u Crkvi, Beograd, 2010, 20.

${ }^{29}$ Usp. Aleksandar ŠMEMAN, Euharistija, Hilandar, 2002, 10.

${ }^{30}$ Usp. Sando, nav. dj., 20.

${ }^{31}$ Usp. Pribislav SIMIĆ, Crkvena umetnost, Beograd, 1994, 14.
} 
Pojam lijepoga, preuzet iz kršćanskog religioznog shvaćanja, utjecat će na sve grane duha u konkretnom narodu, na sve njegove razine, bilo da je riječ o umjetnosti, književnosti, etici, filozofiji i drugim teorijskim oblicima višeg postojanja. U tom odnosu i specifičnim okolnostima nacionalnog postojanja i života, teoretiziranje će biti pretakano u njegovu praktičnost i bit će primijenjeno u istraživanju i gradnji mogućnosti koja će ga voditi i uznositi u svetost.

Ikonografija je istovremeno savršena umjetnost i težnja k vječnoj ljepoti, sve do slika realnoga života kao takvog. U srednjovjekovlju na hramskim su zidovima slikani monasi i svećenici s djecom koja sjede u školskim klupama, sveti liječnici s lijekovima u rukama, što otkriva kulturu tadašnjega života koja se odražava u namještaju, posuđu, životom prostoru kršćanskoga naroda, a što nije bio odraz slikarove mašte nego onovremene stvarnosti. Postojanost boja i trodimenzionalnost ikona ne može dočarati ni suvremena virtualnost. Ljepota u Crkvi počiva i na crkvenoj pjesmi, u govoru i riječima molitve, ali i u doživljaju mirisa tamjana, dodira relikvija, cjelovu ikone, primitku svete pričesti itd.

\section{4. »Problem« ljepote}

Čovjek je biće kojem su vlastite tri egzistencijalne potrebe: potreba za zajedništvom (slašću, hranom, općenjem), žeđ za ljepotom i žeđ za znanjem, a one su neodvojive od življenja vrlina. I nema postojanja bez te inicijative, ali ni bez mogućnosti za stjecanje vrjednota. Ipak, te se potrebe mogu pokazati i kao kamen čovjekova spoticanja. Sve tri potrebe munjevito se očituju i dolaze do izražaja istog trenutka čim je u pitanju demonska obmana ili kad se hrana koristi na neblagoslovljen način. To je ponovni i naopak primjer uspostavljanja odnosa s »drvetom spoznaje dobra i zla«, odnosno, po svetom Grguru Palami, sa slastima osjetilnoga svijeta. »Vidje žena da je stablo dobro za jelo, za oči zamamno, a za mudrost poželjno« (Post 3, 6). Demon, nudeći čovjeku ljepotu, nudi mu ono što odgovara njegovoj prirodi i bez čega čovjek ne može biti čovjek. Zamračujući u njemu milosni dar razlikovanja prolaznog od neprolaznog, privremenog od vječnog, on mu na mjesto prave ljepote, kao što to čini i lažnom hranom i znanjem, podmeće i lažnu ljepotu: podmeće čovjeku prolazno umjesto neprolaznog, raspadljivo umjesto neraspadljivog, smrt umjesto života, tamu umjesto svjetlosti. Lažna ljepota, stjecana iz osjetilnog svijeta, i njezina uporaba, dana je čovjeku da mu, pravilnim odnosom prema njoj, bude predokus vječne ljepote, a demonskim se nagovorom pretvara u tragičnost. Bez Božjega blagoslova, čovjekova zlouporaba ljepote postaje život obmane i privida. ${ }^{32} \mathrm{U}$ tajni $» d r v a$ spoznaje dobra i zla« otkriva se cijeli poredak »korisne uporabe stvari« od prvih

\footnotetext{
${ }^{32}$ Usp. Mitropolit Amfilohije, nav. dj., 56.
} 
do posljednjih dana čovjekove egzistencije i njegov »dijalektički« odnos prema pravoj i lažnoj ljepoti.

Ljepota vanjskih formi iskonski pripadala vrlini i odražava njezinu bit, njezinu srž, dok porok - radi prikrivanja svojih djelovanja - teži da se sakrije ispod forme koja mu nije vlastita. ${ }^{33}$ Stoga se vrlina, da ne bi imala ništa zajedničko s porokom, odriče vanjske ljepote. A porok, pak, na sve načine nastoji da tu formu maskiranja učiniti što efektnijom i efikasnijom. ${ }^{34}$ Crkveni oci prvih vremena nisu se odricali prirodne ljepote. Oni su u prirodnoj čovjekovoj ljepoti i ljepoti prirode stjecali ako ne novi, a ono na nov način osmišljen estetski ideal starine. Oni su revoltirano istupali protiv činitelja poroka svih vrsta i dimenzija. Na sve su načine osuđivali težnju ljudi da svoja tijela ukrašavaju s pomoću odviše raskošnih odijela, dragocjenih ukrasa, kozmetike, jer to, s jedne strane, izaziva buđenje suvišnih strasti, a s druge strane, umanjivanje prirodne ljepote tijela i lica, a katkad je zna i unakaziti. Mnoge imućne žene, iako su prihvaćale kršćanstvo, nisu se mogle osloboditi svojih navika bojanja lica, nošenja vlasulje, neobičnih tkanina, obilja dragog kamenja i zlatnih ukrasa.

Tim se »raspuštenim i sablažnjivim«načinom kićenja poriče istinska ljepota i prikriva svoje pravo lice te se na takav oblik ponašanja gleda iz utilitarističke perspektive i opominje da skupocjenosti i ukrasi povećavaju ljepotu i privlačnost žene, što pobuđuje strast u muškarca. ${ }^{35}$ Tako se već podrijetlo te vrste umjetnosti i samo ukrašavanje držalo neprimjerenim. No, ne kore se samo žene zbog takvog uređivanja, budući da je ono postojalo i kod muškaraca. Muškarci se brižljivo briju, uklanjaju i najmanju dlačicu s podbratka, uvijaju kosu, ukrašavaju glavu, nastoje sakriti sijede vlasi, daju tijelu mladenački izgled i također se često gledaju u ogledalu. Dio nazovikršćanskoga društva već odavno živi samo izvještačenom, umjetnom ljepotom, zaboravivši da u čovjeku postoji prirodna ljepota koja zbog toga može manje doći do izražaja. Očekuje od kršćana da njihov vanjski izgled odgovara duhu njihovih uvjerenja, da odgovara moralnim formama. ${ }^{36}$ Čistoća i jednostavnost kršćanske žene mora biti tako velika da se širi iz njezina srca i na njezin vanjski izgled, na izbor odjeće i sve pojavno.

Ali nisu samo ideali razboritosti i skromnosti poticali rane kršćane na asketsko udaljavanje od raskoši, pretjerivanja i ukrašavanja. Sama gruba i teška stvarnost, stalna spremnost da prihvate i mučeničku smrt za svoje ideale, umanjivali su za njih značenje vanjskoga blagostanja, uključujući i ljepotu, i okretali ih više $\mathrm{k}$ skromnom načinu življenja negoli k onom koji obiluje raskošnošću. Već i socijalni položaj prvih kršćana umnogome je odredio i njihove estetske ideale. ${ }^{37} \mathrm{Ni}$ danas se nije teško u mnogočemu složiti s tim naukom, vodeći ipak

\footnotetext{
${ }^{33}$ Usp. IVAN ZLATOUSTI, Kateheze, Beograd, 2016, 103.

${ }^{34}$ Usp. André GRABAR, Kunst des frühen Christentums, München, 1967, 42, 238.

${ }^{35}$ Usp. KLIMENT ALEKSANDRIJSKI, Pedagog, III. knj., 32 (prev. M. Mijatov, Novi Sad, 1998) i Tertulijan, Ad nat. I, 7.

${ }^{36}$ Usp. Ivan Zlatousti, nav. dj., 106.

${ }^{37}$ Usp. isto, 108.
} 
računa i o tome da vrijeme u kojem danas živimo podrazumijeva načine života koji se i u higijenskom i u socijalnom i u općedruštvenom pogledu prilično razlikuje od prošlosti. $S$ jedne strane, potrebno je uvažiti te promjene, ali, s druge strane, navedena načela mogu biti dobrodošao i koristan korektiv pretjeranostima kojima naše vrijeme obiluje.

\section{Zaključak}

Ranokršćanska estetika je postavila duhovne i moralne vrijednosti iznad usko estetskih i nastojala je čak zamijeniti njima estetske vrijednosti, jer se u rimskom društvu toga vremena osjećala suprotna tendencija. Ljepota kulturnog djelovanja ili govora često je potiskivala površno značenje kulta, a i sam sadržaj govora. Kršćanstvo se moralo u prvoj fazi odreći antičkoga kultnog estetizma, da bi ga potom, ispunivši sve njegove komponente novim značenjem, usvojilo kao vlastiti i obrazložilo njegovu nužnost u transformiranom obliku. Da bi došlo do srednjovjekovnog estetizma, po svoj prilici dubljeg od antičkoga, nova kultura je morala proći svojevrsno »očišćenje« da se, po mogućnosti, odrekne svih prije nje stvorenih umjetničkih vrijednosti, da se vrati »estetici prirode«, da na temelju platonizma i profetizma sazda »estetiku duha« i tek zatim, na novoj razini, rehabilitira »estetiku umjetničkog djelovanja«, ispunivši je novim duhovnim sadržajem. Kršćanska intuicija je dobro osjećala da prebacivanje čovjekove erotske snage iz sfere intimnih uzajamnih odnosa u sferu duhovne ljubavi prema Bogu i bližnjima može postati snažan stimulans razvijanja duhovne dimenzije i pobožnosti. ${ }^{38}$ Taj proces je trajao više stoljeća i bio je ispunjen složenim duhovnim i socijalnim konfliktima. ${ }^{39}$

\footnotetext{
${ }^{38}$ Usp. Vasilije ZJENJKOVSKI, Na pragu zrelosti, Beograd, 1984, 60.

${ }^{39}$ Usp. Bičkov, nav. dj., 244.
} 


\section{Dragomir Sando* \\ The catechetical sense of the concept of beauty \\ Summary}

One of the basic characteristics of pedagogy is beauty. Beauty that in the broadest sense, means all of the aesthetic means of creating a particular way, the existence and the ultimate meaning of the world, and thus the educational system. Beauty thus becomes the property of the cosmological, anthropological, theological, ecclesiological, sociological and other features of the world. The man has perpetrated such a nice man, a perfectly sweet but not being completed, and as such hold's possibilities of eternal life for real luminary of divine light and beauty. Man, as an icon of God and is created with the intention to be a perfectly nice and enlightened because it is God-and made for something much more sublime and infinitely more valuable than anything that exists.

Key words: beauty, church, creation, aesthetics, art, education, formation.

(na engl. prev. Dragomir Sando)

\footnotetext{
* Dragomir Sando, PhD, University of Belgrade, Orthodox Faculty of Theology; Address: Mije Kovačevića, 11b, SRB-11060 Belgrade, Serbia; E-mail: dragsando@yahoo.com.
} 